\title{
Influencing Factors on the Usefulness of an Earthquake Early Warning System during the 2017 Mexico City Earthquakes
}

\author{
Jaime Santos-Reyes (D) \\ Grupo de Investigacion SARACS, SEPI-ESIME, Zac., Instituto Politecnico Nacional, \\ Ciudad de Mexico 07738, Mexico; jrsantosr@hotmail.com
}

check for updates

Citation: Santos-Reyes, J.

Influencing Factors on the Usefulness of an Earthquake Early Warning System during the 2017 Mexico City Earthquakes. Sustainability 2021, 13, 11499. https://doi.org/10.3390/ su132011499

Academic Editor: Tommaso Caloiero

Received: 6 September 2021

Accepted: 14 October 2021

Published: 18 October 2021

Publisher's Note: MDPI stays neutral with regard to jurisdictional claims in published maps and institutional affiliations.

Copyright: (C) 2021 by the author. Licensee MDPI, Basel, Switzerland. This article is an open access article distributed under the terms and conditions of the Creative Commons Attribution (CC BY) license (https:/ / creativecommons.org/licenses/by/ $4.0 /)$.

\begin{abstract}
The paper presents the results of an ongoing research project on the performance of the SASMEX system following the two earthquakes that hit Mexico City in 2017, (a) the 7 September, and (b) the 19 September. In an earlier work, some preliminary findings on the perceived usefulness of the system have been reported. The aim of the present study is the identification of the precursors leading to the outcome variable ('Usefulness of the SASMEX system'). An ordinal logistic regression analysis has been conducted. The influential factors leading to (a) are the following: the 1985 earthquake experience, drills participation, current knowledge, knowledge on what to do, fear during the tremors, education level, earthquake severity impact. The identified influential factors leading to (b) are the following: knowledge vs. drills, fear of building collapsing, and warning time. The main conclusion of the study is that the outcome is warning time dependent following an event. When there is 'enough time' to take protective actions, such as in (a), the probability of the system being considered Useful is higher than otherwise. Conversely, if there is not enough warning time, such as in (b), the probability of the system being considered Not useful is higher than otherwise.
\end{abstract}

Keywords: 2017 earthquakes; SASMEX usefulness; emergency response; warning time

\section{Introduction}

Earthquake early warning (EEW) systems are essential in mitigating the impact of earthquakes by providing timely warnings to those living in seismic zones. Further, EEWs should be 'people-centred' [1-3]. The challenge facing countries that have implemented such systems is that people should be prepared how to react to the alerts [4-8] and that the systems should be 'faster' and more reliable in providing 'timely' information $[1,3,9,10]$. There is evidence of the success of early warning systems (e.g., hurricane early warning systems) worldwide when effectively implemented [3]. However, there is also evidence when such systems fail (lack of infrastructure, not operational, etc.) to provide the warnings during an emergency [11].

On 7 September 2017 at 23:53 hours, an earthquake of magnitude 8.2 originated in the Gulf of Tehuantepec, $133 \mathrm{~km}$ on the southwest of Pijijiapan, Chiapas, Mexico; it was felt in the south and central part of the country, including Mexico City [12,13]. The Mexican Seismic Alert System (SASMEX) alerted residents of the capital city 92-120 s. before the actual earthquake [14,15] (see [14,16] for further details of the records of some of the seismological stations and the seismic alert report). Consequently, 102 people were killed, 119,000 homes, schools, and hospitals were damaged in the affected states; it is also believed that 3 million people were left without water and over one million without electricity [17,18]; however, there were no reported fatalities in the capital city [18]. Twelve days later, on 19 September 2017 at 13:25 pm and with a 7.1 of magnitude [19], a second earthquake occurred, and this time causing the death of 228 people in the capital city (and 141 in other affected states), over 11,000 damaged buildings, 6 million and over 4 million residents without water and electricity, respectively [18-22]. However, the SASMEX system fail to alert residents; in fact, people reported that the seismic alert went off just a few 
seconds after the ground shaking $[2,15]$. (See $[23,24]$ for further details of the records of some of the seismological stations and the seismic alert report).

An earlier work on the performance of the SASMEX system during the two earthquakes was reported in [2]. Given the lack of data at the time, in that work, the results of an analysis of association between several independent variables with the outcome (i.e., 'Usefulness of the SASMEX') were reported. Moreover, a full account of the context of the SASMEX and the earthquakes were also presented in [2]. Given the ordinal (or ordered) nature of the outcome variable (i.e., $1=$ "Not at all useful", $5=$ "Very useful"), in the present work, the results of an ordinal logistic regression analyses are presented. The study aims at the identification of the influencing predictors leading to the ordered outcome variable; however, the analysis of the recorded data on the seismological stations and the seismic alerts are not within the scope of the present study.

\subsection{Ordinal Logistic Regression Models}

There are several types of ordinal logistic regression (OLR) models that may be used for analysing the ordinal response outcome. That is, the continuation ratio model (CRM) $[25,26]$, the adjacent categories model (ACM) [25,26], and the proportional odds model (POM) [27]. The latter is the most used [27-31]. The assumption of the POM is that the underlying binary models (where the ordinal response is dichotomized) have the same coefficients; the logit coefficients for each explanatory variable (covariate) are the same across the ordinal response categories. This is called the proportional odds (PO) (or parallel lines) assumption. However, the parallel-line assumption is often violated. To overcome this limitation, the partial proportional odds model (PPOM) (or the generalised ordinal logit model) is used [32-35]. In what follows, the background of the POM and PPOM are given and based on the work reported in [36].

\subsubsection{Proportional Odds Models (POMs)}

A binary logistic regression model estimates the odds of experiencing an event for the dichotomous outcome variable for a given set of explanatory variables or predictors; the logistic regression can be expressed as [37]:

$$
\begin{gathered}
\ln \left(Y^{\prime}\right)=\operatorname{logit}[\pi(\underline{x})]=\ln [\pi(\underline{x}) / 1-\pi(\underline{x})] \\
=\alpha+\beta_{1} X_{1}+\beta_{2} X_{2}+\cdots+\beta_{p} X_{p}
\end{gathered}
$$

where $\pi_{j}(\underline{x})=\pi\left(Y \leq j \mid x_{1}, x_{2}, \cdots, x_{p}\right)$ is the probability of being at or below category $j$, for a given set of covariates, $j=1,2, \cdots, J-1, \alpha_{j}$ are the cut-points and $\beta_{1}, \beta_{2}, \cdots, \beta_{p}$ are the logit coefficients. For $j$ categories, the POM estimates $J-1$ cut-points. The POM assumes the logit coefficients for the underlying binary models as being the same across all cut-points.

In an OLR, on the other hand, the response variable has more than two categories or levels. The model estimates the probability being at or below a specific outcome level given a set of predictors. The OLR model can be defined in the logit form as [38,39]:

$$
\begin{gathered}
\operatorname{logit}\left[\left(Y \leq j \mid x_{1}, x_{2}, \cdots, x_{p}\right)\right] \\
=\alpha_{j}+\left(-\beta_{1} X_{1}-\beta_{2} X_{2}-\cdots-\beta_{p} X_{p}\right)
\end{gathered}
$$

To estimate the ln (odds) of being at or below the $j$ category, the POM can be expressed as,

$$
\begin{gathered}
\ln \left(Y^{\prime}\right)=\operatorname{logit}[\pi(\underline{x})]=\ln [\pi(\underline{x}) / 1-\pi(\underline{x})] \\
=\ln \left(\pi\left(Y \leq j \mid x_{1}, x_{2}, \cdots, x_{p}\right) \mid \pi\left(Y>j \mid x_{1}, x_{2}, \cdots, x_{p}\right)\right) \\
=\alpha_{j}+\left(-\beta_{1} X_{1}-\beta_{2} X_{2}-\cdots-\beta_{p} X_{p}\right)
\end{gathered}
$$

\subsubsection{Partial Proportional Odds Models (PPOMs)}

As mentioned above, the PPOM or generalized ordinal logistic regression model, extends the PO model by relaxing the parallel line assumption. In the PPOM, if a predictor 
violates the assumption, then its effect can be estimated freely across different levels of the outcome variable. The model takes the form of:

$$
\begin{gathered}
\ln \left(Y_{j}^{\prime}\right)=\ln \left[\pi_{j}(\underline{x}) / 1-\pi_{j}(\underline{x})\right] \\
=\alpha_{j}+\left(\beta_{1 j} X_{1}+\beta_{2 j} X_{2}+\cdots+\beta_{p j} X_{p}\right)
\end{gathered}
$$

Finally, Equation (4) can also be expressed as [33,34]:

$$
\begin{gathered}
\operatorname{logit}\left[\left(Y>j \mid x_{1}, x_{2}, \cdots, x_{p}\right)\right] \\
=\ln \pi\left(Y>j \mid x_{1}, x_{2}, \cdots, x_{p}\right) / \pi\left(Y \leq j \mid x_{1}, x_{2}, \cdots, x_{p}\right) \\
=\alpha_{j}+\left(\beta_{1 j} X_{1}+\beta_{2 j} X_{2}+\cdots, \beta_{p j} X_{p}\right)
\end{gathered}
$$

In Equations (4) and (5), $\alpha_{j}$ are the cut-points or intercepts; $\beta_{1 j}, \beta_{2 j}, \cdots, \beta_{p j}$ are the logit coefficients. A positive logit coefficient indicates that an individual is more likely to be in a higher category as opposed to a lower category of the response variable [36].

\section{Materials and Methods}

\subsection{Ordinal Logistic Regression Models}

As already mentioned, the present study is part of an ongoing research on the residents of the capital city reactions to the usefulness of the SASMEX system in relation to the 2017 earthquakes. The variables considered in the analysis have been those reported in [40]. The non-probability and cross-sectional study were conducted just a few weeks after the two earthquakes; the sample size of the present study is $n=1,644$. (For further details on the data collection and the participants' consent of the study, see $[2,40])$.

\subsubsection{Dependent Variables}

As with the early work, the following two questions were employed for the response variable, "Usefulness of the SASMEX" system during the 07 and 19 September earthquakes: "In relation to the 7 September earthquake, how useful was the SASMEX for you?" and "In relation to the 19 September earthquake, how useful was the SASMEX for you?" Respondents rated their responses according to a five Likert type scale ( $1=$ "Not at all useful", $5=$ "Very useful"). Given that in ordered logit regression between the predictors and the outcome variable, small cell observations often make the analysis unstable [29]. Given that our interest lies mainly whether respondents considered the system "Useful" or "Not useful", hence the original five ordinal response categories were reduced to the following three levels, i.e.: (a) 07 September earthquake ( 1 = "Not useful" (24.07\%); 2 = "Somewhat useful" $(12.12 \%)$; and $3=$ "Useful" (63.81\%)); (b). 19 September earthquake ( $1=$ "Not useful" (76.14\%); 2 = "Somewhat useful" (9.68\%); and $3=$ "Useful" (14.18\%)).

\subsubsection{Predictor Variables}

Table 1 shows seven sets of explanatory variables considered in the analysis. As mentioned in a previous section, the present study employs these sets of predictor variables described in detail in [40]. It should be mentioned that the considered explanatory variables apply for the two cases. Moreover, the employed questionnaire, participants were asked to rate their answers to the perceived 'fear of building collapsing' during the ground shaking, and the 'intensity of fear' experienced during the earthquake for each of the events, i.e., the 07 and 19 September earthquakes (Table 1). 
Table 1. Precursors used for the ordinal logistic regression analyses.

\begin{tabular}{|c|c|}
\hline Explanatory Variables & Description \\
\hline $\begin{array}{l}\text { 1. Demographics } \\
\text { Age } \\
\text { Sex }\end{array}$ & $\begin{array}{c}\text { In years, range }=\text { " } 13-65 "(\text { Mean }=31.64 ; S D=12.65) \\
1 \text { if woman; } 0 \text { otherwise. }\end{array}$ \\
\hline Level education & $\begin{array}{c}1 \text { if High level; } 0 \text { otherwise. (High level = Undergraduate and } \\
\text { Postgraduate; Low level = Primary to Preparatory). }\end{array}$ \\
\hline $\begin{array}{l}\text { Occupation } \\
\text { 2. Earthquake experience } \\
\text { 1985 earth. experience } \\
\text { 3. Earthquake drills }\end{array}$ & 1 if employees and retired; 0 otherwise. \\
\hline Frequency drills & $\begin{array}{c}0=0 \text { drills } / \text { year (base group), } 2=1 \text { drill } / \text { year, } 2=2 \text { drills } / \text { year, } 3=3 \\
\text { drills } / \text { year } 4=4 \text { drills } / \text { year }, 5=6 \text { drills } / \text { year } 6=12 \text { drills } / \text { year }\end{array}$ \\
\hline Drill experience & $\begin{array}{l}1 \text { if Yes; } 0 \text { otherwise. (It should be highlighted that the SASMEX system is a } \\
\text { key component when conducting drills, see [2] for further details.) }\end{array}$ \\
\hline $\begin{array}{l}\text { 4. The SASMEX system } \\
\text { Warning time } \\
\text { 5. Earthquake knowledge } \\
\text { Knowledge on what to do }\end{array}$ & 1 if "I know what to do"; 0 otherwise. \\
\hline Knowledge vs. drills & $\begin{array}{c}1 \text { if Yes; } 0 \text { otherwise. (i.e., "Do you think that having a good knowledge on } \\
\text { what to do during an earthquake, mass drillings are not necessary?") } \\
\text { Continuous (scale } 0-10 ; 0=\text { "Knowing nothing"; } 10=\text { "Knowing } \\
\text { everything"). (It refers to the participants existing knowledge on issues } \\
\text { related to seismic risk of the city, e.g., knowledge on the seismic zones } \\
\text { within the city, etc.). }\end{array}$ \\
\hline $\begin{array}{l}\text { 6. Perception seismic risk } \\
\text { Likelihood of harm }\end{array}$ & $\begin{array}{c}\text { Continuous (scale } 0-10 ; 0=\text { "Absolutely no chance"; } 10=\text { "Absolutely } \\
\text { certain") }\end{array}$ \\
\hline $\begin{array}{l}\text { Severity of harm } \\
\text { PVC (Perception of the Vulnerability of the City) } \\
\text { 7. Psychological reactions }\end{array}$ & $\begin{array}{l}\text { Continuous (scale } 0-10 ; 0=\text { "Not serious", } 10=\text { "Severe"). } \\
\text { Continuous (Two items were considered to measure it, } \alpha=0.67 \text { ). }\end{array}$ \\
\hline Negative affect & Continuous (Five items were considered to measure it, $\alpha=0.75$ ) \\
\hline $\begin{array}{l}\text { Fear during } 07 \text { Sept. earthquake } \\
\text { Fear during } 19 \text { Sept earthquake }\end{array}$ & Continuous (scale $0-10 ; 0=$ "Not at all"; $10=$ "A lot") \\
\hline $\begin{array}{l}\text { Fear during } 19 \text { Sept. earthquake } \\
\end{array}$ & Continuous (scale $0-10 ; 0=$ "Not at all"; $10=$ "A lot") \\
\hline $\begin{array}{l}\text { Fear collapsing building/house } 07 \text { Sept. earthquake } \\
\text { Fear collapsing building/house } 19 \text { Sept. earthquake }\end{array}$ & $\begin{array}{l}1 \text { if "A lot"; } 0 \text { otherwise. } \\
1 \text { if "A } \operatorname{lot}^{\prime} ; 0 \text { otherwise. }\end{array}$ \\
\hline
\end{tabular}

\subsection{Statistical Analysis}

Descriptive analysis was conducted by frequency and cross-tabulation analyses. Dummy variables were created for categorical variables (Table 1). The Kruskal-Wallis and the Mann-Whitney $U$ tests were performed when comparing three and two groups, respectively. The multicollinearity was assessed by the Variance Inflation Factor (VIF), where the average IVFs were 1.02 and 1.08 for the predictor variables related to the $7 \& 19$ September earthquakes, respectively. Given that the average IVFs were not 'substantially' greater than ' 1 ' [41], then it was confirmed that collinearity was not a problem for these models.

Given that studies on people's response to earthquake early warning systems is scarce, the employed approach to variable selection has been purposeful selection [42]. In the univariable analysis, the $p$-value threshold was set at $25 \%$ (i.e., some explanatory variables may be missed at the traditional $p<0.05$ level of significance at this stage of the analysis [42] (p. 91), see Tables 2 and 5). The identified covariates were included in the final adjusted multivariable ordinal logistic regression models at $p<0.05$ (Tables 3 and 6). Hence, for each of the cases considered in the present study (Section 3), the potential set of predictors were fitted to the proportional odds model (POM). Then, the fitted model was assessed by employing the Brant test of proportionality (or parallel-line test) [43]. If the parallel line assumption was violated for any of the explanatory variables tested, then, the partial proportional odds model (PPOM) was used [34,35]. All the statistical tests of significance were set up at $p<0.05$. Finally, all tests of were performed by employing the software Stata program (version 15.1, StataCorp., College Station, TX, USA). 
Table 2. Univariable ordinal logistic regression for the outcome and the 7 September earthquake.

\begin{tabular}{|c|c|c|c|c|c|c|c|}
\hline \multirow{2}{*}{\multicolumn{2}{|c|}{ Variables }} & \multirow[b]{2}{*}{ Measures } & \multicolumn{3}{|c|}{ Usefulness of the SASMEX System $^{\dagger}$} & \multirow[b]{2}{*}{$O R^{++\dagger}$} & \multirow[b]{2}{*}{$p^{t+t}$} \\
\hline & & & $\begin{array}{c}\text { Not Useful } \\
(n=393)\end{array}$ & $\begin{array}{l}\text { Somewhat } \\
(n=198)\end{array}$ & $\begin{array}{l}\text { Useful } \\
(n=1042)\end{array}$ & & \\
\hline \multirow{6}{*}{ Demographics } & \multirow{2}{*}{ Sex } & Women & $218(23.70)$ & $113(12.28)$ & $589(64.02)$ & \multirow[t]{2}{*}{1.028} & \multirow[t]{2}{*}{0.782} \\
\hline & & Men (base) & $175(24.54)$ & $85(11.92)$ & $453(63.53)$ & & \\
\hline & \multirow[b]{2}{*}{ Education } & High & $137(25.80)$ & $62(11.68)$ & $332(62.52)$ & \multirow[t]{2}{*}{0.906} & \multirow[t]{2}{*}{0.360} \\
\hline & & Low (base) & $256(23.23)$ & $136(12.34)$ & $710(64.43)$ & & \\
\hline & \multirow{2}{*}{ Occupation } & Employees & $226(23.30)$ & $114(11.75)$ & $630(64.95)$ & \multirow[t]{2}{*}{1.123} & \multirow[t]{2}{*}{0.256} \\
\hline & & $\begin{array}{l}\text { Students } \\
\text { (base) }\end{array}$ & $167(25.19)$ & $84(12.67)$ & $412(62.14)$ & & \\
\hline \multirow{2}{*}{$\begin{array}{l}\text { Earthquake } \\
\text { experience }\end{array}$} & \multirow{2}{*}{$\begin{array}{c}1985 \\
\text { earthquake }\end{array}$} & Yes & $111(20.04)$ & $59(10.65)$ & $384(69.31)$ & \multirow[t]{2}{*}{1.443} & \multirow[t]{2}{*}{$<0.001$} \\
\hline & & No (base) & $282(26.21)$ & $139(12.92)$ & $655(60.87)$ & & \\
\hline \multirow{9}{*}{$\begin{array}{c}\text { Earthquake } \\
\text { drills }\end{array}$} & \multirow{7}{*}{$\begin{array}{l}\text { Frequency of } \\
\text { drills }\end{array}$} & 0/year (base) & $26(41.27)$ & $10(15.87)$ & $27(42.86)$ & & \multirow[t]{7}{*}{0.029} \\
\hline & & 1 & $50(26.32)$ & $23(12.11)$ & $117(61.58)$ & 2.064 & \\
\hline & & 2 & $30(25.64)$ & $10(8.55)$ & 77 (65.81) & 2.383 & \\
\hline & & 3 & $9(23.68)$ & $3(7.89)$ & $26(68.42)$ & 2.685 & \\
\hline & & 4 & $17(24.64)$ & $3(4.35)$ & 49 (71.01) & 2.916 & \\
\hline & & 6 & $104(21.89)$ & $70(14.74)$ & 301 (63.37) & 2.330 & \\
\hline & & 12/year & $150(23.15)$ & 76 (11.73) & $422(65.12)$ & 2.418 & \\
\hline & \multirow{2}{*}{$\begin{array}{c}\text { Drill } \\
\text { experience }\end{array}$} & Yes & $354(34.40)$ & 176 (11.63) & 983 (64.97) & \multirow[t]{2}{*}{1.840} & \multirow[t]{2}{*}{0.001} \\
\hline & & No (base) & 38 (33.33) & $21(18.42)$ & $55(48.25)$ & & \\
\hline \multirow{2}{*}{ The SASMEX } & \multirow{2}{*}{ Warning time } & Time varies & 107 (27.37) & $41(10.49)$ & $243(62.15)$ & \multirow[t]{2}{*}{0.874} & 0.256 \\
\hline & & Other (base) & $286(23.03)$ & $157(12.64)$ & 799 (64.33) & & \\
\hline & Fear & A lot & 141 (20.17) & $68(9.73)$ & $490(70.10)$ & 1.580 & $<0.001$ \\
\hline $\begin{array}{l}\text { Psychological } \\
\text { reactions }\end{array}$ & $\begin{array}{l}\text { Collapsing } \\
\text { building }\end{array}$ & $\begin{array}{l}\text { Not at all } \\
\text { (base) }\end{array}$ & $252(26.98)$ & $130(13.92)$ & $552(59.10)$ & & \\
\hline & Knowledge & Yes & $291(22.25)$ & $142(10.86)$ & $875(66.9)$ & 1.795 & $<0.001$ \\
\hline Earthquake & what to do & No (base) & $102(31.38)$ & $56(17.23)$ & 167 (51.38) & & \\
\hline knowledge & Knowledge & Yes & $240(24.72)$ & $121(12.46)$ & $610(62.82)$ & 0.897 & 0.295 \\
\hline & vs. drills & No (base) & $150(23.11)$ & $74(11.40)$ & $425(65.49)$ & & \\
\hline Continuous & variables & Measures & $\begin{array}{l}\text { Not useful } \\
\text { Mean Rank }\end{array}$ & $\begin{array}{l}\text { Somewhat } \\
\text { Mean Rank }\end{array}$ & $\begin{array}{c}\text { Useful } \\
\text { Mean Rank }\end{array}$ & $O R^{\dagger+\dagger}$ & $p^{t+t}$ \\
\hline & $\begin{array}{l}\text { Likelihood of } \\
\text { harm }\end{array}$ & Scale $0-10$ & 828.64 & 817.20 & 812.57 & 0.989 & 0.640 \\
\hline $\begin{array}{l}\text { Perception of } \\
\text { seismic risk }\end{array}$ & $\begin{array}{c}\text { Severity of } \\
\text { harm }\end{array}$ & Scale $0-10$ & 827.80 & 829.34 & 810.58 & 0.981 & 0.421 \\
\hline & PVC & $(\alpha=0.75)$ & 810.19 & 768.16 & 828.85 & 1.081 & 0.189 \\
\hline Demographics & Age & Years & 775.55 & 777.48 & 840.14 & 1.012 & 0.003 \\
\hline $\begin{array}{l}\text { Earthquake } \\
\text { knowledge }\end{array}$ & $\begin{array}{c}\text { Current } \\
\text { Knowledge }\end{array}$ & Scale $0-10$ & 736.50 & 792.30 & 846.53 & 1.107 & $<0.001$ \\
\hline & Negative & $(\alpha=0.67)$ & 765.80 & 797.73 & 839.97 & 1.181 & 0.003 \\
\hline $\begin{array}{l}\text { Psychological } \\
\text { reactions }\end{array}$ & $\begin{array}{l}\text { Fear during } \\
07 \\
\text { earthquake }\end{array}$ & Scale $0-10$ & 689.70 & 764.38 & 869.64 & 1.127 & $<0.001$ \\
\hline
\end{tabular}

${ }^{+}$Total $\%$ in rows may not add up to $100 \%$ because of decimal rounding. Differences in total $n=1644$ are due to missing values in items.

${ }^{+t} \%$ within the category of the outcome variable. ${ }^{++t}$ Univariable ordinal logistic regression. 
Table 3. Multivariable ordinal logistic regression results of the SASMEX performance during the 7 September earthquake.

\begin{tabular}{|c|c|c|c|c|c|c|c|c|}
\hline \multicolumn{2}{|c|}{ Predictors } & \multirow{2}{*}{$\begin{array}{c}\text { Measures } \\
\text { High } \\
\text { Low (base) }\end{array}$} & \multirow{2}{*}{$\begin{array}{c}\text { Coef. } \\
-0.3180\end{array}$} & \multirow{2}{*}{$\begin{array}{c}\text { Std. Err. } \\
0.1180\end{array}$} & \multirow{2}{*}{$\begin{array}{c}z \\
-2.70\end{array}$} & \multirow{2}{*}{$\frac{p \text {-Value }}{0.007^{* *}}$} & \multirow{2}{*}{$\begin{array}{c}\text { OR } \\
0.727\end{array}$} & \multirow{2}{*}{$\begin{array}{c}\begin{array}{c}95 \% \text { CI } \\
\text { [Lower-Upper] }\end{array} \\
{[0.5773-0.9168]}\end{array}$} \\
\hline Demographics & $\begin{array}{l}\text { Level of } \\
\text { education }\end{array}$ & & & & & & & \\
\hline $\begin{array}{l}\text { Earthquake } \\
\text { experience }\end{array}$ & 1985 earthquake & $\begin{array}{c}\text { Yes } \\
\text { No (base) }\end{array}$ & 0.3124 & 0.1216 & 2.57 & $0.010 *$ & 1.367 & [1.076-1.734] \\
\hline \multirow{2}{*}{$\begin{array}{c}\text { Earthquake } \\
\text { preparedness }\end{array}$} & $\begin{array}{l}\text { Knowledge on } \\
\text { what to do }\end{array}$ & $\begin{array}{c}\text { Yes } \\
\text { No (base) }\end{array}$ & 0.4950 & 0.1290 & 3.84 & $0.000 * * *$ & 1.640 & [1.274-2.112] \\
\hline & $\begin{array}{c}\text { Current } \\
\text { Knowledge }\end{array}$ & Continuous & 0.0708 & 0.0275 & 2.57 & 0.010 * & 1.073 & [1.016-1.133] \\
\hline $\begin{array}{l}\text { Earthquake drill } \\
\text { participation }\end{array}$ & $\begin{array}{c}\text { Drill } \\
\text { participation }\end{array}$ & $\begin{array}{c}\text { Yes } \\
\text { No (base) }\end{array}$ & 0.5899 & 0.1930 & 3.06 & $0.002 * *$ & 1.804 & [1.135-2.633] \\
\hline Risk perception & $\begin{array}{c}\text { Earthquake } \\
\text { severity impact }\end{array}$ & Continuous & -0.0518 & 0.0248 & -2.09 & 0.037 * & 0.950 & [0.905-0.9968] \\
\hline $\begin{array}{l}\text { Psychological } \\
\text { reactions }\end{array}$ & $\begin{array}{l}\text { Fear during the } \\
\text { ground shaking }\end{array}$ & Continuous & 0.1275 & 0.0180 & 7.06 & $0.000 * * *$ & 1.136 & [1.096-1.177] \\
\hline \multicolumn{9}{|c|}{ Model Fit } \\
\hline \multirow{2}{*}{ Model } & \multirow{2}{*}{ Observations } & \multicolumn{2}{|c|}{ Log likelihood } & $d f$ & \multicolumn{2}{|c|}{ Information criterion } & \multicolumn{2}{|c|}{ Likelihood ratio test } \\
\hline & & II (null) & II (model) & $\mathrm{dr}$ & AIC & BIC & LR Chi $^{2}$ & $p$ \\
\hline POM & 1612 & -1427.364 & -1373.657 & 9 & 2765.314 & 2813.781 & 107.41 & $0.000^{* * *}$ \\
\hline
\end{tabular}

${ }^{*} p<0.05 ;{ }^{* *} p<0.01 ; * * *<0.001$. Abbreviations: POM, Proportional Odds Model; OR, odds ratio; CI, confidence interval; AIC, Akaike Information Criterion; BIC, Bayesian Information Criterion.

\section{Results}

\subsection{Influence Factors on the Usefulness of the SASMEX during the 7 September Earthquake}

Table 2 shows the results when fitting a univariable ordinal logistic regression model for each explanatory variable (Table 1). Table 2 shows the unadjusted odds ratio effects of each of the potential predictors. For example, participants that experienced the 1985 earthquake, the odds of the SASMEX being 'Useful' versus the combined 'Somewhat useful' and 'Not useful' categories are 1.443 times higher than subjects that did not experience the earthquake. Similarly, for a one unit increase in the variable intensity of fear test score, the odds of the SASMEX being 'Useful' versus the combined 'Somewhat useful' and 'Not useful' categories are 1.127 greater.

The results of the univariable analysis highlighted that of seventeen potential predictors, ten were significant at $25 \%$. Table 3 shows the results of the multivariable ordinal logistic regression model where the following precursors to the outcome have been identified: education level, the 1985 earthquake experience, knowledge on what to do, drill participation, current (existing) knowledge, the perceived severity of impact of an earthquake occurring in the city, and the experienced fear during the ground shaking. When the Brant test was conducted to the fitted model, it was found that the proportional odds assumption was met $\left(\chi^{2}(7)=5.98, p=0.542\right)$.

The results highlighted that participants that experienced the 1985 earthquake $(\mathrm{OR}=1.367$; 95\% CI: 1.076-1.734), those that have participated in earthquake drills (OR $=1.804 ; 95 \%$ CI: 1.135-2.633), participants knowledgeable on what actions to take during an earthquake occurrence $(\mathrm{OR}=1.640 ; 95 \% \mathrm{CI}: 1.274-2.112)$, those that considered to have good knowledge on earthquakes at the time (OR $=1.073 ; 95 \%$ CI: 1.016-1.133), and those that experienced higher intensity of fear during the ground shaking $(\mathrm{OR}=1.136$; 95\% CI: 1.096-1.177) tended to consider the SASMEX system as being 'Useful'. However, those participants with higher education ( $\mathrm{OR}=0.727 ; 95 \% \mathrm{CI}$ : $0.5773-0.9168)$, and those that perceived a low severity impact of earthquakes (OR $=0.950 ; 95 \%$ CI: 0.905-0.9968) were less supportive of the usefulness of the SASMEX system at the time.

When conducting the marginal effects analysis (Table 4), the results show that, on average, respondents with higher education are 5.7 percentage points more likely than those with low education to say that the SASMEX was 'Not useful', and about 7 percentage points less likely to say that the SASMEX is 'Useful'. Further, on average, respondents that 
experienced the 1985 earthquake are 6.7 percentage points more likely than those that did not experienced it to say that the SASMEX is 'useful', and about 5.3 percentage points less likely to say that the system is 'Not useful'.

Table 4. Marginal effects on the outcome variable for the case of the 7 September earthquake.

\begin{tabular}{ccccccccccccc}
\hline \multirow{2}{*}{ Variables } & \multicolumn{3}{c}{ Not Useful } & \multicolumn{3}{c}{ Somewhat Useful } & \multicolumn{3}{c}{ Useful } \\
\cline { 2 - 11 } & & AME & Std. Err. & $p$ & AME & Std. Err. & $p$ & AME & Std. Err. & $p$ \\
\hline Demographics & $\begin{array}{c}\text { Level of } \\
\text { education }\end{array}$ & 0.0564 & 0.0213 & $0.008^{* *}$ & 0.0131 & 0.0046 & $0.005^{* *}$ & -0.0695 & 0.0258 & $0.007 * *$ \\
\hline $\begin{array}{c}\text { Earthquake } \\
\text { experience }\end{array}$ & $\begin{array}{c}1985 \\
\text { earthquake }\end{array}$ & -0.0527 & 0.020 & $0.008^{* *}$ & -0142 & 0.0058 & $0.014^{*}$ & 0.0670 & 0.0256 & $0.009 * *$ \\
\hline $\begin{array}{c}\text { Earthquake } \\
\text { preparedness }\end{array}$ & $\begin{array}{c}\text { Knowledge } \\
\text { what to do }\end{array}$ & -0.0921 & 0.025 & $0.000^{* * *}$ & -0.0196 & 0.0047 & $0.000^{* * *}$ & 0.1118 & 0.0298 & $0.000^{* * *}$ \\
\hline $\begin{array}{c}\text { Earthquake drill } \\
\text { participation }\end{array}$ & $\begin{array}{c}\text { Drill } \\
\text { participation }\end{array}$ & -0.1140 & 0.040 & $0.005^{* *}$ & -0.0204 & 0.005 & $0.000^{* * *}$ & 0.1345 & 0.0451 & $0.003 * *$ \\
\hline
\end{tabular}

${ }^{*} p<0.05 ;{ }^{* *} p<0.01 ;{ }^{* *} p<0.001$. Abbreviations: AME, Average Marginal Effect.

The results also highlighted that, on average, participants that know what actions to take during the earthquake are 11.2 percentage points more likely than those that did not know what to do to say that the SASMEX was 'Useful', and about 9.2 percentage points less likely to say that the system is 'Not useful'. Finally, the marginal effects show that, on average, respondents that participated in earthquake drills are 13.5 percentage points more likely than those that did not participate in drills to say that the SASMEX was 'Useful', and about 11.4 percentage points less likely to say that the system is 'Not useful' (Table 4).

Figure 1 shows the predicted probabilities of the continuous variables and the outcome categories (it should be highlighted that the predicted probabilities are within the range of the observed values, i.e., by considering the original scale of these variables, i.e., from 0-10, see Table 1). For example, Figure 1a,b shows the probability of the SASMEX system being 'Useful' is around $71 \%$ for individuals that consider insignificant the impact of earthquakes; however, for those that consider a severe impact of these events, the probability is around $61 \%$ (i.e., the probability of the SASMEX being 'Useful' decreases as the severity of harm increases). Conversely, the probability of the system being 'Not useful' increases from 19\% at around $24 \%$ for those that considered a severe impact of earthquakes (see Section 3.2).

Figure 1f show the probability of the response variable when considering the variables related to 'current knowledge' and 'intensity of fear' following a similar pattern. In relation to the former, the probability of the system being 'Useful' increases from around 54\% ('Knowing nothing') to $68 \%$ ('Knowing everything'). Moreover, when considering the two categories ('Useful' vs. 'Not useful') and for those that have participated in earthquake drills. The results highlight that the likelihood of the SASMEX being considered 'Useful' increases with the intensity of fear during the ground shaking and that respondents that have participated in drills were more likely to consider the system 'Useful' than those that did not. Conversely the two lines at the bottom, the probability of the system being considered 'Not useful' decreases with the intensity of fear and that those subjects that participated in drills were less likely to see the system 'Not useful' (and the gap decreases with the intensity of fear, as shown in Figure 1f).

\subsection{Influence Factors on the Usefulness of the SASMEX during the 19 September Earthquake}

As with the previous case, the results of the univariable ordinal logistic regression are shown in Table 5. The analysis has highlighted that of the original seventeen variables, ten have been significant at 25\% (Section 2.2). Following the purposeful selection approach (Section 2.2), at the end, the following precursors that have a significant effect on the ordinal outcome were those related to age, warning time, knowledge on what to do during the shaking, the fear of collapsing building/house, and the knowledge vs. drills, as shown in Table 6. When fitting the data to the multivariable ordinal logistic regression model, the Brant test of parallel-lines assumption was performed and the results showed that it was 
violated $\left(\chi^{2}(5)=24.23, p<0.001\right)$. Hence, the POM was excluded and the PPOM was fitted to the data; the results revealed that the parameter estimates for the constrained variables warning time, knowledge vs. drills and the fear of collapsing buildings are all the same (Table 6). However, the coefficients of the variables related to age and knowledge on what to do vary across the regressions.

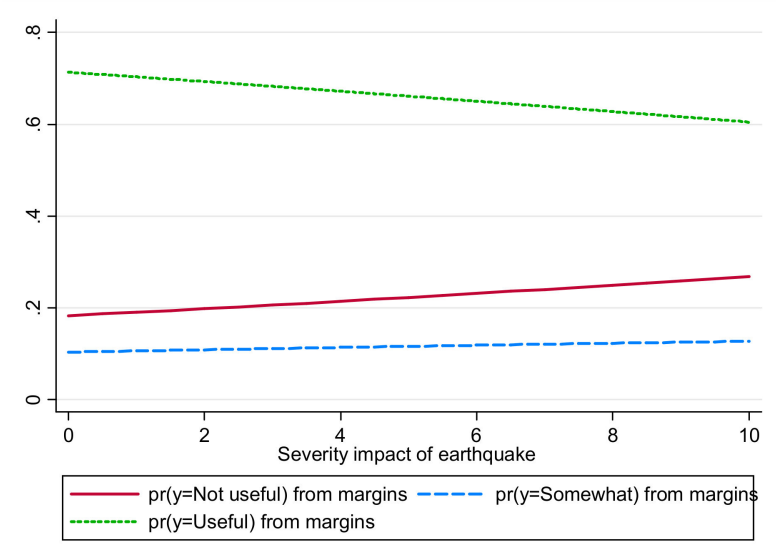

(a)

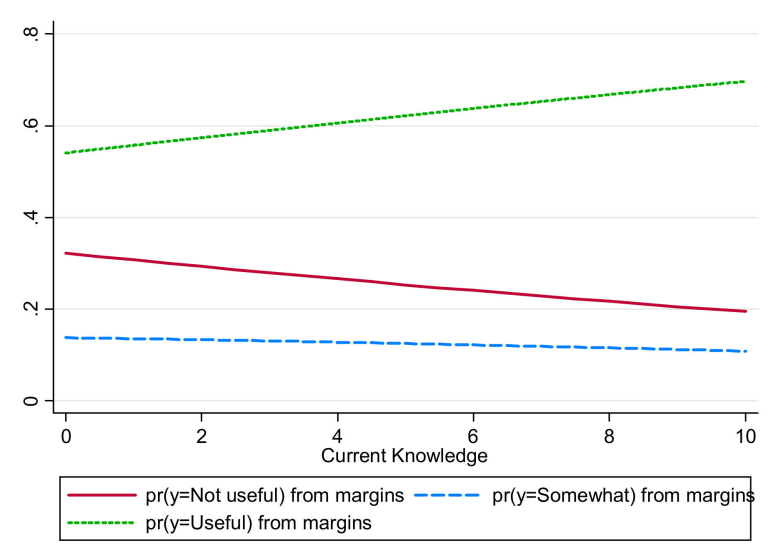

(c)

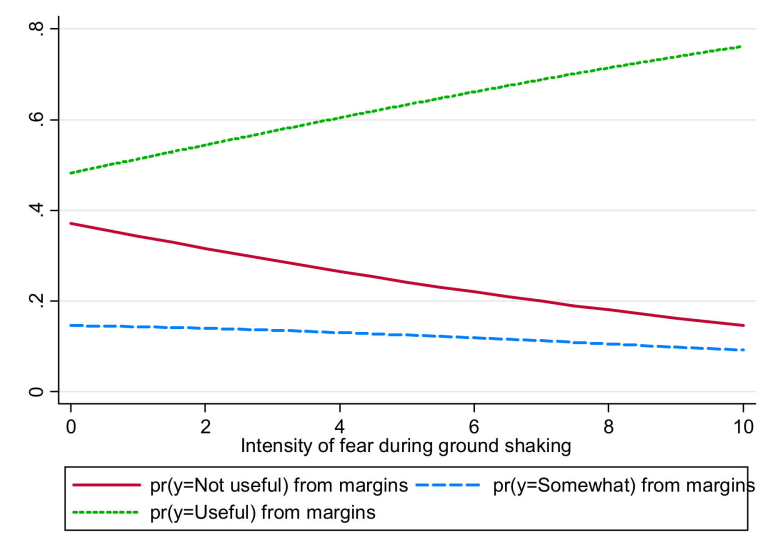

(e)

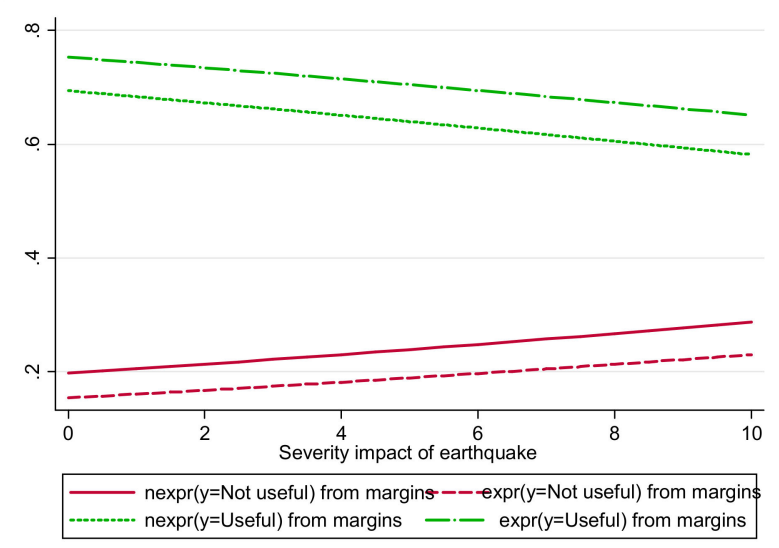

(b)

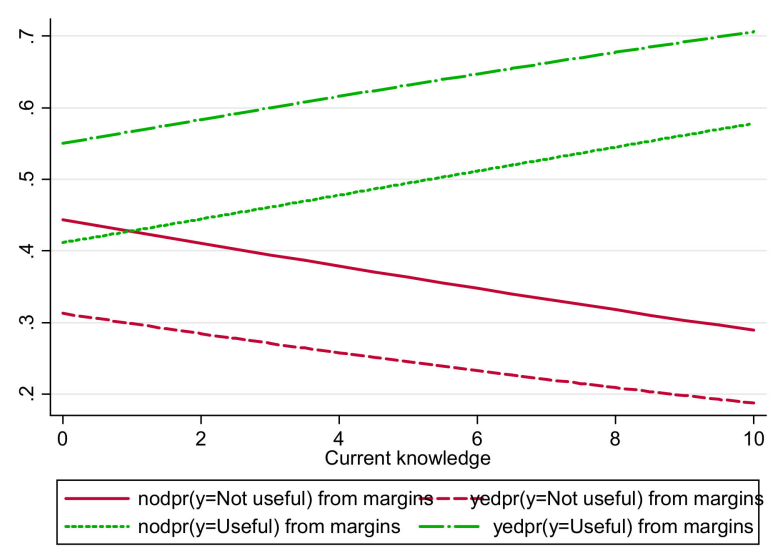

(d)

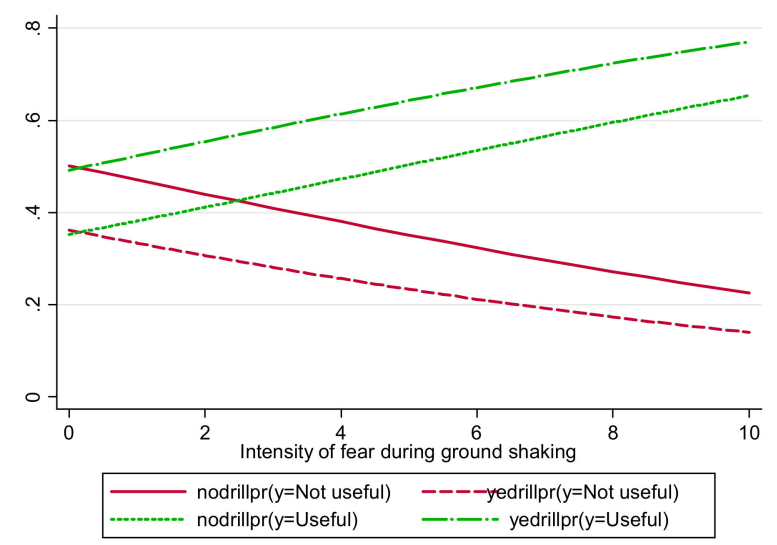

$(\mathbf{f})$

Figure 1. Projected probabilities of the usefulness of the SASMEX system during the 07 September earthquake. (a) Severity impact of earthquake; (b) Severity impact, 1985 earthquake experience ('expr') and no-1985 earthquake experience ('nexpr'); (c) Current knowledge; (d) Current knowledge, drill participation ('yedpr') and no-drill participation ('nodpr'); (e) Intensity of fear during ground shaking; (f) Intensity of fear, drill participation ('yedrillpr') and no-drill participation ('nodrillpr'). 
Table 5. Univariable ordinal logistic regression for the outcome and the 19 September earthquake.

\begin{tabular}{|c|c|c|c|c|c|c|c|}
\hline \multirow{2}{*}{\multicolumn{2}{|c|}{ Variables }} & \multirow[b]{2}{*}{ Measures } & \multicolumn{3}{|c|}{ Usefulness of the SASMEX System $^{\dagger}$} & \multirow[b]{2}{*}{$O R^{++\dagger}$} & \multirow[b]{2}{*}{$p^{t+t}$} \\
\hline & & & $\begin{array}{c}\text { Not Useful } \\
(n=393)\end{array}$ & $\begin{array}{c}\text { Somewhat } \\
(n=198)\end{array}$ & $\begin{array}{c}\text { Useful } \\
(n=1042)\end{array}$ & & \\
\hline \multirow{5}{*}{ Demographics } & Sex & $\begin{array}{c}\text { Women } \\
\text { Men (base) }\end{array}$ & $\begin{array}{l}699(75.65) \\
552(76.77)\end{array}$ & $\begin{array}{l}86(9.31) \\
73(10.15)\end{array}$ & $\begin{array}{l}139(15.04) \\
94(13.07)\end{array}$ & 1.081 & 0.502 \\
\hline & \multirow[b]{2}{*}{ Education } & High & $405(75.70)$ & $45(8.41)$ & 85 (15.89) & 1.065 & 0.606 \\
\hline & & Low (base) & $846(76.35)$ & $114(10.29)$ & $148(13.36)$ & & \\
\hline & \multirow{2}{*}{ Occupation } & Employees & $708(72.62)$ & $89(9.13)$ & $178(18.26)$ & 1.730 & $<0.001$ \\
\hline & & $\begin{array}{l}\text { Students } \\
\text { (base) }\end{array}$ & $543(81.29)$ & $70(10.48)$ & $55(8.23)$ & & \\
\hline \multirow{2}{*}{$\begin{array}{l}\text { Earthquake } \\
\text { experience }\end{array}$} & \multirow{2}{*}{1985 earthquake } & Yes & $388(69.66)$ & $49(8.80)$ & $120(21.54)$ & 1.800 & $<0.001$ \\
\hline & & No (base) & $860(79.56)$ & 109 (10.08) & $112(10.36)$ & & \\
\hline \multirow{9}{*}{$\begin{array}{l}\text { Earthquake } \\
\text { drills }\end{array}$} & \multirow{7}{*}{$\begin{array}{l}\text { Frequency of } \\
\text { drills }\end{array}$} & 0/year (base) & $49(76.56)$ & $7(10.94)$ & $8(12.50)$ & & 0.881 \\
\hline & & 1 & $152(79.17)$ & $18(9.38)$ & $22(11.46)$ & 0.870 & \\
\hline & & 2 & $93(79.49)$ & $9(7.69)$ & $15(12.82)$ & 0.870 & \\
\hline & & 3 & $29(74.36)$ & $3(7.69)$ & $7(17.95)$ & 1.180 & \\
\hline & & 4 & $52(75.36)$ & $9(13.04)$ & $8(11.59)$ & 1.050 & \\
\hline & & 6 & $364(76.31)$ & $48(10.06)$ & $65(13.63)$ & 1.030 & \\
\hline & & 12/year & 488 (75.19) & $60(9.24)$ & $101(15.56)$ & 1.107 & \\
\hline & \multirow{2}{*}{ Drill experience } & Yes & $1168(76.84)$ & $139(9.14)$ & $213(14.01)$ & 0.730 & 0.136 \\
\hline & & No (base) & $80(69.57)$ & $18(15.65)$ & $17(14.78)$ & & \\
\hline \multirow{2}{*}{ The SASMEX } & \multirow{2}{*}{ Warning time } & Time varies & $316(80.41)$ & $31(7.89)$ & $46(11.70)$ & 0.730 & 0.022 \\
\hline & & Other (base) & $935(748)$ & $128(10.24)$ & $187(14.96)$ & & \\
\hline \multirow{2}{*}{$\begin{array}{l}\text { Psychological } \\
\text { reactions }\end{array}$} & \multirow{2}{*}{$\begin{array}{l}\text { Fear Collapsing } \\
\text { building }\end{array}$} & A lot & $901(780.08)$ & $99(8.58)$ & $154(13.34)$ & 0.722 & 0.008 \\
\hline & & $\begin{array}{l}\text { Not at all } \\
\text { (base) }\end{array}$ & $350(71.57)$ & $60(12.27)$ & 79 (16.16) & & \\
\hline \multirow{4}{*}{$\begin{array}{l}\text { Earthquake } \\
\text { knowledge }\end{array}$} & \multirow{4}{*}{$\begin{array}{l}\text { Knowledge what } \\
\text { to do } \\
\text { Knowledge vs. } \\
\text { drills }\end{array}$} & Yes & $991(75.42)$ & $117(8.90)$ & $206(15.68)$ & 1.307 & 0.065 \\
\hline & & No (base) & $260(79.03)$ & $42(12.77)$ & $27(8.21)$ & & \\
\hline & & Yes & 731 (74.97) & $100(10.26)$ & 144 (14.77) & 1.242 & 0.069 \\
\hline & & No (base) & $515(78.87)$ & $57(8.73)$ & $81(12.40)$ & & \\
\hline \multicolumn{2}{|c|}{ Continuous variables } & Measures & $\begin{array}{l}\text { Not useful } \\
\text { Mean Rank }\end{array}$ & $\begin{array}{l}\text { Somewhat } \\
\text { Mean Rank }\end{array}$ & $\begin{array}{c}\text { Useful } \\
\text { Mean Rank }\end{array}$ & $O R^{+++}$ & $p^{t+t}$ \\
\hline \multirow{3}{*}{$\begin{array}{l}\text { Perception of } \\
\text { seismic risk }\end{array}$} & $\begin{array}{l}\text { Likelihood of } \\
\text { harm }\end{array}$ & Scale $0-10$ & 819.37 & 830.02 & 830.62 & 1.003 & 0.900 \\
\hline & Severity of harm & Scale $0-10$ & 818.20 & 798.40 & 858.52 & 1.005 & 0.842 \\
\hline & PVC & $(\alpha=0.75)$ & 825.92 & 776.90 & 831.74 & 0.961 & 0.560 \\
\hline Demographics & Age & Years & 789.78 & 802.73 & 1008.15 & 1.026 & $<0.001$ \\
\hline $\begin{array}{l}\text { Earthquake } \\
\text { knowledge }\end{array}$ & $\begin{array}{l}\text { Current } \\
\text { Knowledge }\end{array}$ & Scale $0-10$ & 805.31 & 809.64 & 891.82 & 1.046 & 0.132 \\
\hline \multirow{2}{*}{$\begin{array}{l}\text { Psychological } \\
\text { reactions }\end{array}$} & $\begin{array}{l}\text { Negative } \\
\text { emotions }\end{array}$ & $(\alpha=0.67)$ & 823.35 & 816.66 & 818.38 & 1.022 & 0.732 \\
\hline & $\begin{array}{l}\text { Fear during } 07 \\
\text { earthquake }\end{array}$ & Scale $0-10$ & 820.84 & 768.70 & 789.21 & 0.970 & 0.134 \\
\hline
\end{tabular}

\footnotetext{
${ }^{\dagger}$ Total $\%$ in rows may not add up to $100 \%$ because of decimal rounding. Differences in total $n=1644$ are due to missing values in items.

${ }^{t+} \%$ within the category of the outcome variable. ${ }^{++\dagger}$ Univariable ordinal logistic regression.
} 
Table 6. Multivariable partial proportional logistic regression results of the SASMEX performance during the 19 September earthquake.

\begin{tabular}{|c|c|c|c|c|c|c|c|c|c|}
\hline \multirow[b]{2}{*}{ Predictors } & \multirow[b]{2}{*}{ Measures } & \multicolumn{4}{|c|}{ Somewhat Useful and Useful vs. Not Useful } & \multicolumn{4}{|c|}{ Useful vs. Not Useful and Somewhat Useful } \\
\hline & & Coef. & $p$ & OR & $\begin{array}{c}95 \% \text { CI } \\
\text { [Lower- } \\
\text { Upper] }\end{array}$ & Coef. & $p$ & OR & $\begin{array}{c}95 \% \text { CI } \\
\text { [Lower- } \\
\text { Upper] }\end{array}$ \\
\hline $\begin{array}{l}\text { Demographics: } \\
\text { Age }\end{array}$ & Years & 0.027 & $0.001 * *$ & 1.027 & [1.018-1.036] & 0.038 & $0.001 * *$ & 1.038 & [1.027-1.05] \\
\hline $\begin{array}{l}\text { The SASMEX: } \\
\text { Warning time }\end{array}$ & $\begin{array}{l}\text { Time varies } \\
\text { Other (base) }\end{array}$ & -0.506 & $0.015 *$ & 0.603 & [0.402-0.905] & -0.506 & $0.015 *$ & 0.603 & [0.402-0.905] \\
\hline \multicolumn{10}{|l|}{$\begin{array}{c}\text { Earthquake } \\
\text { preparedness: }\end{array}$} \\
\hline $\begin{array}{l}\text { Knowledge vs. } \\
\text { drills }\end{array}$ & $\begin{array}{c}\text { Yes } \\
\text { No (base) }\end{array}$ & 0.293 & $0.017 *$ & 1.340 & [1.053-1.706] & 0.293 & $0.017 *$ & 1.340 & [1.053-1.706] \\
\hline $\begin{array}{l}\text { Psychological } \\
\text { reactions: } \\
\text { Fear collapsing } \\
\text { building during } \\
\text { the earthquake }\end{array}$ & $\begin{array}{c}\text { A lot } \\
\text { Not at all (base) }\end{array}$ & -0.431 & $0.001 * *$ & 0.650 & {$[0.507-0.833]$} & -0.431 & $0.001 * *$ & 0.650 & {$[0.507-0.833]$} \\
\hline \multicolumn{10}{|c|}{ Model Fit } \\
\hline \multirow{2}{*}{ Model } & \multirow{2}{*}{ Observations } & & Log likelihoo & & & \multicolumn{2}{|c|}{$\begin{array}{l}\text { Information } \\
\text { criterion }\end{array}$} & \multicolumn{2}{|c|}{ Likelihood ratio test } \\
\hline & & & II (null) & $\begin{array}{c}\text { II } \\
\text { (model) }\end{array}$ & df & AIC & $\mathrm{BIC}$ & $\begin{array}{c}\mathrm{LR} \\
\mathrm{Chi}^{2}\end{array}$ & $p$ \\
\hline PPOM & 1628 & & -1145.676 & -1102.676 & 9 & 2222.919 & 2271.475 & 86.43 & $0.000^{* * *}$ \\
\hline
\end{tabular}

${ }^{*} p<0.05 ;{ }^{* *} p<0.01 ;{ }^{* * *} p<0.001$. Abbreviations: PPOM, Partial Proportional Odds Model; OR, odds ratio; CI, confidence interval; AIC,

Akaike Information Criterion; BIC, Bayesian Information Criterion.

The results have highlighted those respondents that considered having a good knowledge on protective actions (and that earthquake drills may be not necessary) were more likely to say that the SASMEX was 'Useful' (OR = 1.340; 95\% CI:1.053-1.706). However, respondents that most fear building/house collapsing during the ground shaking $(\mathrm{OR}=0.650 ; 95 \% \mathrm{CI}: 0.507$ to 0.833$)$, and those that considered that the warning "time varies" (OR $=0.603$; 95\% CI: 0.402-0.905) were less supportive of the usefulness of the SASMEX system.

Regarding the variables that violated the parallel-lines assumptions, the results revealed that older participants were associated with the likelihood of being in a higher level of the outcome variable ('Usefulness of the SASMEX'). The effects became much stronger when the outcome variable moved from 'Not useful' to 'Useful' (Figure 2). Further, the figure shows the probability of the SASMEX system being 'Not useful' is around $82 \%$ for 13-year-old participants and it decreases as the age increases (see Section 4.3 for more on this).

Similarly, the participants knowledge on what to do during the tremors was associated with the likelihood of being in a higher category level of the 'Usefulness of the SASMEX' system. The effects became much stronger when the outcome level moved from low to high; further, the largest difference being that knowledgeable individuals were less likely to place themselves in the 'Not useful' category.

A marginal effects analysis was conducted only for those variables that met the parallel-line assumption. The results show that, on average, respondents that considered the warning time varies are 5.2 percentage points more likely than those the respondent 'other' to say that the SASMEX was 'Not useful', and about 3.4 percentage points less likely to say that the SASMEX is 'Useful'. Regarding the knowledge vs. drills, the results have highlighted that, on average, knowledgeable respondents are 3.4 percentage points more likely than those that responded no to say that the SASMEX was 'Useful', and about 5.3 percentage points less likely to say that the system is 'Not useful'. Finally, the marginal effects show that, on average, participants that fear the building collapsing are 7.9 percentage points more likely than those that did not to say that the SASMEX was 'Not useful', and about 5.3 percentage points less likely to say that the system is 'Useful'. 


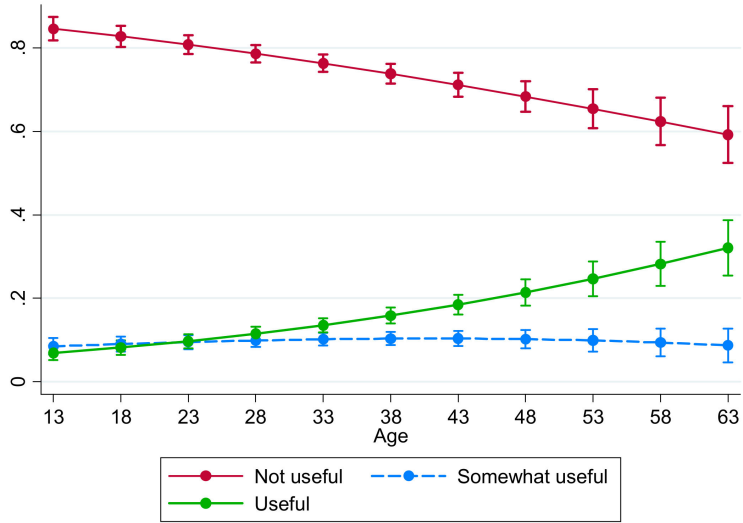

Figure 2. Predicted probability when considering the age of the participants and the outcome variable.

Figure 3 shows that the probability of the SASMEX system being 'Not useful' increases from around $66 \%$ to $79 \%$ as the fear of the building collapsing increases. Conversely, the probability of the system being 'Useful' decreases to around $1.5 \%$ with the fear of building collapsing. A similar trend is observed for the case of the precursor 'warning time'. However, the probability of the SASMEX system being 'Not useful' decreases from around $80 \%$ to $74 \%$ for the case of respondents that considered that having a good knowledge on what to do, earthquake drills may not be necessary.

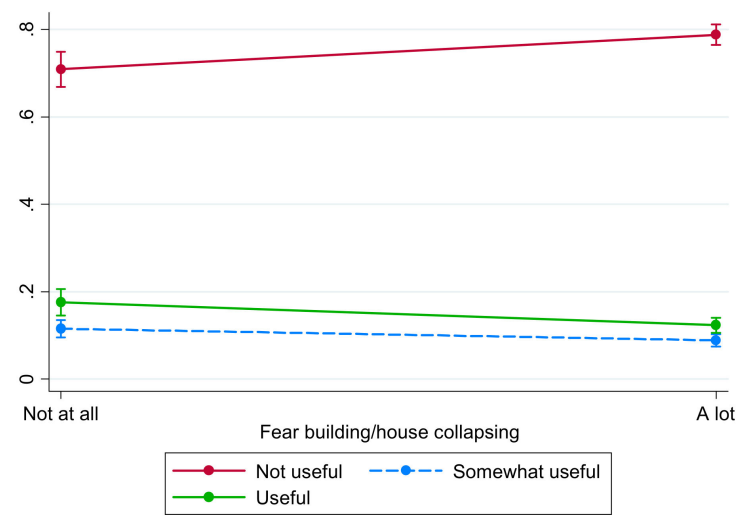

(a)

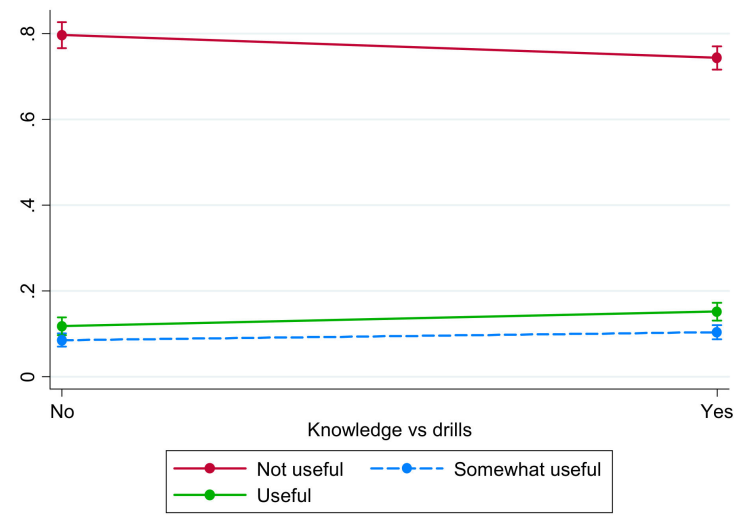

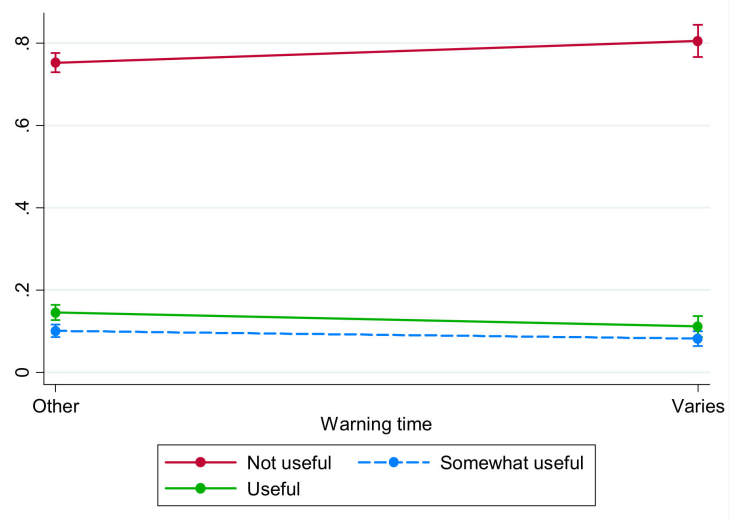

(b)

(c)

Figure 3. Predicted probabilities of the usefulness of the SASMEX system for the case of the 19 September earthquake. (a) Fear of collapsing building during the ground shaking; (b) Warning time knowledge; (c) Knowledge vs. drills. 


\section{Discussion}

\subsection{On the Influencing Factors on the Usefulness of the SASMEX System-7 September Earthquake}

Respondents that experienced the 1985 earthquake, those that have participated in earthquake drills, the knowledgeable on what actions to take during an earthquake, those that had a good 'current (or existing) knowledge' on issues related to seismic risk in the capital city, and those that experienced higher intensity of fear during the ground shaking tended to consider the SASMEX system as 'Useful'.

The results are consistent with what has been reported in the literature; for example, direct experience of earthquakes and its consequences can be a strong motivator of preparedness [44]. Following the devastating 1985 earthquake that struck Mexico City [45], scholars and other organizations were motivated and determined to develop and implement an earthquake early warning system $[46,47]$. Current knowledge on the vulnerability of the city to seismic risk could help to enhance respondents' capacity to look for new knowledge about it [48] (p.289). Scholars have found that current knowledge would provide subjects a "trained capacity" to gather additional information [49] (p. 200) [50].

Drills are part of the continuous process of emergency preparedness [51,52]. Mass earthquake drills are conducted yearly in the capital city and aided by the SASMEX system, and the participants of the study consider this as a positive thing to do [40]. Negative affect (fear) plays a crucial role in the process of decision-making during an earthquake emergency. For example, in [53] it has been reported that individuals experiencing fear "might be receptive to information to engage in a danger control mechanism", and that may be the case of the earthquake alert system. The results also have highlighted that the probability of the SASMEX being 'Useful' increases with the intensity of fear experienced by the participants during the ground shaking (Figure 1e,f). Moreover, those subjects that participated in earthquake drills were less likely to see the system 'Not useful'. Again, the finding is consistent with those reported on mass earthquake drills where participants agree on participating in several drills per year [54].

However, participants with high education, and those that perceived a low severity impact of earthquakes were less supportive of the usefulness of the SASMEX system. In relation to the former, one explanation may be the fact that the seismic alert went off 92 s. [14] or 120-124 s. [15] before the actual ground shaking. The time of occurrence may have influenced their perception on the usefulness of the system, i.e., the earthquake occurred at 23:53 p.m. For example, in the field of fire safety, it has been found that building occupants do not respond to fire alarms due to the loss of confidence in the warning system because of nuisance fire alarms, among other [55]. However, more research is needed on this.

Participants that did not experience the 1985 earthquake disaster were more likely to consider the SASMEX system Not useful (Figure 1a,b). The finding is consistent when comparing younger participants $(<45)$ with those over 46 years old; the over 46 years old $(M d n=8)$ perceived a higher level than younger participants $(M d n=7)$ of the severity of the consequences of an earthquake occurring in the capital city $(U=194113.5$, $z=-2.102, p<0.05, r=0.05)$. Again, having a direct experience of earthquakes motivates preparedness [44] and the lack of an adequate knowledge of younger participants during an emergency contributes to the increase in social vulnerability to seismic risk $[56,57]$.

Overall, the presented results have highlighted that the perceived 'Usefulness of the SASMEX system' is warning time dependent following the event. That is, when there is 'enough time' (i.e., 92-124 s. before the ground shaking) to take some protective actions, the probability of the system being 'Useful' is higher than otherwise (Figure 1).

\subsection{On the Influencing Factors on the Usefulness of the SASMEX System-19 September Earthquake}

The explanatory variables that have a significant effect on the ordinal outcome were those related to warning time, the fear of collapsing building/house, and the knowledge vs. drills. Respondents that considered having a good knowledge on protective actions (and that earthquake drills may be not necessary) were more likely to say that the SASMEX was 
'Useful' (Table 6). These findings have highlighted those participants know the importance of the SASMEX system in the process of earthquake disaster risk reduction.

However, participants that most feared building/house collapsing during the ground shaking, and those that considered the warning "time varies" were less supportive of the usefulness of the SASMEX system. These findings were expected given the fact that, in principle, early warning systems should alert people well in advance to be able to take some protective actions $[1,58]$. Given that there was not enough warning time before the actual ground shaking, participants were confused about it, i.e., $59.3 \%$ of respondents considered $60 \mathrm{~s}$. as the warning time [2]. The experts on the system contend that the warning time is "close to 60 s." [46] (p. 156), mainly because of the major events occurring at the Pacific coast at about $320 \mathrm{~km}$ from the capital city. Although, in [47] the authors argue that the warning time "may be as large as $60-90$ s." (p. 1452) to earthquakes originating in the subduction zone. However, earthquakes not always are originated within this zone, as demonstrated by the 19 September earthquake, where the epicentre was located inland, $120 \mathrm{~km}$ from the capital city [19].

The results have highlighted the need to further educate the residents of the capital city on the functioning, strengths, and limitations of the system [2]. The following two comments by the experts on the system may summarize what has been already discussed: "It can, without a doubt, if we can improve the algorithms and have more seismographs throughout the country, we would have a more effective alert. For example, if we had a seismograph just above the hypocentre [of the 19 September earthquake], we probably would have had up to five more seconds before the waves arrived" [59]. In a similar vein, "To me, this shows that we should not enamoured of the technology and simply install seismic early warning systems without thinking of the social issues. Any early warning system should have a clearly thought-out strategy as to who will be warned," "After more than 25 years, the Mexican seismic early warning system is still lacking these procedures that I believe should be a governmental responsibility." [60].

Overall, the presented results have highlighted that the perceived 'Usefulness of the SASMEX system' is warning time dependent following an event. That is, when there is not enough warning time, such as the present case, the probability of the system being 'Not useful' is higher than otherwise (Figure 3).

\subsection{Limitations of the Study}

Some of the main limitations of the study are the following:

- The study was for convenience and the results should not be generalised to the population of the capital city.

- The results presented are based on a set of predictors (Table 1); other variables could be incorporated, for example, those related to people's psychological reaction when hearing the seismic alert (e.g., [5]), among others. Nevertheless, the results presented herein are the starting point in gaining a better understanding of people's reactions to earthquake early warning systems.

- The usefulness of the SASMEX system was assessed by data collected a few months after the two earthquakes; this may have induced some bias, however, and so more research is needed to see whether the results are replicated without an event. This is part of an ongoing research project.

- The results presented herein did not address why the opposite view of the performance of the SASMEX system during the 19 September earthquake by two of the most vulnerable groups of the population, i.e., young, and old participants (Figure 2). Although the variable age was not identified as a predictor, it is crucial to further investigate this issue in order to gain a better understanding of their perception and response to seismic alerts. Moreover, a risk factor of earthquake death may be that related to 'staying asleep' for the case of the elderly, an issue that should also be further investigated. That is, they may have problems in hearing the seismic alert during a seismic emergency at night; further details on this issue have been discussed in [54]. 
- The variable related to 'current knowledge' was used to give an insight of the participants' self-reported 'current (or existing) knowledge' on issues related to the seismic vulnerability of the capital city. However, to be able to assess, for example, the resident's information-seeking behaviour, in relation to the SASMEX system, other variables should be taken into consideration, e.g., 'information need' $[48,50]$. This needs further research.

- More generally, the presented results need to be seen in the light of the assumptions made in the study.

\section{Conclusions}

This paper has presented the results of an ongoing research project on the usefulness of the SASMEX system following the two earthquakes that hit Mexico City in 2017, (a) the 07 September, and (b) the 19 September (just twelve days in between them). The aim of the study has been the identification of precursors leading to the outcome variable ('Usefulness of the SASMEX system'). Given the ordered nature of the outcome variable ('Not useful', 'Somewhat useful', and 'Useful'), a POM (Proportional Odds Model) and PPOM (Partial Proportional Odds Model) were used for the analysis of (a) and (b), respectively. The key conclusion of the study was that the perceived 'Usefulness of the SASMEX system' is warning time dependent following the event. That is, when there is 'enough time' to take protective actions such as in (a), the probability of the system being considered 'Useful' is higher than otherwise (Figure 1). Conversely, if there is not 'enough time' such as in (b), the probability of the system being considered 'Not useful' is higher than otherwise (Figure 3). Nevertheless, it is unclear whether the results can be replicated when there is no such an event such as the present time. This is part of an ongoing research project.

The influential factors leading to the outcome variable for the case (a) were the following: level of education, 1985 earthquake experience, earthquake drills, knowledge on what to do, current knowledge, intensity of fear during the ground shaking, fear of building collapsing, and the severity impact of earthquakes.

The identified influential factors leading to the outcome variable for the case (b) were the following: severity of harm, fear of building/house collapsing during the tremor, and the warning time.

Funding: This research was funded by CONACYT (Consejo Nacional de Ciencia y Tecnologia), grant number CONACYT No.-248219 and SIP-IPN: No-20210785.

Institutional Review Board Statement: Not applicable.

Informed Consent Statement: Not applicable.

Data Availability Statement: Data is contained within the article.

Acknowledgments: The author wishes to acknowledge the research team, external experts and those who helped to conduct the survey, many of whom provided valuable discussions. Additionally, thanks to the anonymous journal reviewers for their helpful and insightful comments.

Conflicts of Interest: The author declares no conflict of interest.

\section{References}

1. Basher, R. Global early warning systems for natural hazards: Systematic and people-centred. Philos. Trans. R. Soc. A: Math. Phys. Eng. Sci. 2006, 364, 2167-2182. [CrossRef] [PubMed]

2. Santos-Reyes, J. How useful are earthquake early warning systems? The case of the 2017 earthquakes in Mexico City. Int. J. Disaster Risk Reduct. 2019, 40, 101148. [CrossRef]

3. UNDP (United Nations Development Program). Five Approaches to Build Early Warning Systems. 2018. Available online: https://www.eurasia.undp.org/content/rbec/en/home/library/environment_energy/five--approaches--to--build-functional--early--warning--systems.html (accessed on 20 January 2021).

4. Freddi, F.; Galasso, C.; Cremen, G.; Dall'Asta, A.; Di Sarno, L.; Giaralis, A.; Gutiérrez-Urzúa, F.; Málaga-Chuquitaype, C.; Mitoulis, S.A.; Petrone, C.; et al. Innovations in earthquake risk reduction for resilience: Recent advances and challenges. Int. J. Disaster Risk Reduct. 2021, 60, 102267. [CrossRef] 
5. Huggins, T.J.; Yang, L.; Zhang, J.; Tan, M.L.; Prasanna, R. Psychological Effects of Dominant Responses to Early Warning Alerts. Int. J. Ambient. Comput. Intell. 2021, 12, 1-15. [CrossRef]

6. Sutton, J.; Fischer, L.; James, L.E.; Sheff, S.E. Earthquake early warning message testing: Visual attention, behavioral responses, and message perceptions. Int. J. Disaster Risk Reduct. 2020, 49, 101664. [CrossRef]

7. McBride, S.K.; Bostrom, A.; Sutton, J.; de Groot, R.M.; Baltay, A.S.; Terbush, B.; Bodin, P.; Dixon, M.; Holland, E.; Arba, R.; et al. Developing post-alert messaging for shakeAlert, the earthquake early warning system for the West Coast of the United States of America. Int. J. Disaster Risk Reduct. 2020, 50, 101713. [CrossRef]

8. Sellnow, D.D.; Jones, L.M.; Sellnow, T.L.; Spence, P.; Lane, D.R.; Haarstad, N. The IDEA Model as a Conceptual Framework for Designing Earthquake Early Warning (EEW) Messages Distributed via Mobile Phone Apps. In Earthquakes-Impact, Community Vulnerability and Resilience; IntechOpen: London, UK, 2019; pp. 11-20.

9. Amato, A. Some reflections on tsunami early warning systems and their impact, with a look at the NEAMTWS. Boll di Geofis Teor ed Appl. 2020, 61, 403-420.

10. Minson, S.E.; Baltay, A.S.; Cochran, E.S.; Hanks, T.C.; Page, M.; McBride, S.K.; Milner, K.R.; Meier, M.-A. The Limits of Earthquake Early Warning Accuracy and Best Alerting Strategy. Sci. Rep. 2019, 9, 1-13. [CrossRef]

11. BBC (British Broadcasting Corporation). Indonesia Earthquake and Tsunami: How Warning System Failed the Victims. 2018. Available online: https:/ /www.bbc.com/news/world--asia--45663054 (accessed on 30 April 2021).

12. Mega, E.R. Deadly Mexico earthquake had unusual cause. Nat. Cell Biol. 2017, 549. [CrossRef]

13. Godinez-Dominguez, E.; Tena-Colunga, A.; Perez-Rocha, L.E.; Archundia-Aranda, H.I.; Gomez-Bernal, A.; Ruiz-Torres, R.P.; Escamilla-Cruz, J.L. The September 7, 2017 Tehuantepec, Mexico, earthquake: Damage assessment in masonry struc-tures for housing. Int. J. Disaster Risk Reduct. 2021, 56, 102123. [CrossRef]

14. CIRES (Centro de Instrumentación y Registro Sísmico). Sismo del 07 de septiembre de 2017. Boletin del Sistema de Alerta Sísmica Mexicano (SASMEX). 2017. Available online: http://www.cires.org.mx/reportes_sasmex/sasmex_reporte_20170907_235032_es. php (accessed on 9 October 2021).

15. Hidalgo, S.; Lajous, A. 11 Segundos Vitales: ¿Por QUé No Sonó a Tiempo la Alerta Sísmica El 19 Septiembre? 2017. Available online: https: / / www.animalpolitico.com/2017/11/alerta--sismica--sensores--cdmx/ (accessed on 25 June 2021).

16. SSN. Sismo de Tehuantepec (2017-09-07 23:49 Mw 8.2). 2017. Available online: http://www.ssn.unam.mx/sismicidad/reportes-especiales/2017/SSNMX_rep_esp_20170907_Tehuantepec_M82.pdf (accessed on 9 October 2021).

17. ReliefWeb. Mexico: Sismo 8.2 grados Richter resporte de situacion No. 01 de la Oficina del Coordinador Residente (al 13/09/2017). 2017. Available online: https:/ / reliefweb.int/report/mexico/m--xico--sismo--82--grados--richter--reporte--de--situaci--n--no-01--de--la--oficina--del (accessed on 25 June 2021).

18. CENAPRED. Acciones en el Marco de la Respuesta de Salud Mental Frente al Sismo del 19 de Septiembre de 2017: Lecciones Aprendidas y Buenas Prácticas; CNPD: Secretaría de Gobernación, Mexico, 2018.

19. Franke, K.W.; Candia, G.; Mayoral, J.M.; Wood, C.M.; Montgomery, J.; Hutchinson, T.; Morales-Velez, A. Observed building damage patterns and foundation performance in Mexico City following the 2017 M7.1 Puebla-Mexico City earthquake. Soil Dyn Earthquake Eng. 2019, 125, 105708. [CrossRef]

20. Aldaz, P. Sismo del 19-S afectó 11 mil 495 inmuebles. 2018. Available online: https://www.eluniversal.com.mx/metropoli/ cdmx/sismo--del--19--s--afecto--11--mil--495--inmuebles (accessed on 9 October 2021).

21. CDHDF. El Estado Que Guarda La Garantía de Los Derechos Humanos de Las Personas Damnificadas Por el Sismo de Sep-Tiembre de 2017 en la Ciudad de México-Radiografía a un Año Del Desastre; CDHDF: Álvaro Obregón, Mexico, 2018.

22. Santos-Reyes, J.; Gouzeva, T. Emotional and behavioural responses to the 19 September 2017 earthquake: The case of the occupants of three multi-storey buildings. Disaster Prev. Manag. Int. J. 2021, 30, 412-428. [CrossRef]

23. SSN. Sismo del día 19 de septiembre de 2017, Puebla-Morelos (M 7.1). 2017. Available online: http://www.ssn.unam.mx/ sismicidad/reportes--especiales/2017/SSNMX_rep_esp_20170919_Puebla--Morelos_M71.pdf (accessed on 9 October 2021).

24. CIRES (Centro de Instrumentación y Registro Sísmico). Sismo del 19 de septiembre de 2017. Boletin del Sistema de Alerta Sísmica Mexicano (SASMEX). 2017. Available online: .http://www.cires.org.mx/reportes_sasmex/sasmex_reporte_20170919_131504_es. php?\%20\%20\%20fecha_aviso=2017--09--19\&hora_aviso=18:14:40\& (accessed on 30 April 2021).

25. Silva-Abreu, M.N.; Siquiera, A.L.; Caiaffa, W.T. Ordinal logistic regression in epidemiological studies. Rev Saude Publica. 2009, 43, $1-11$.

26. Bürkner, P.-C.; Vuorre, M. Ordinal Regression Models in Psychology: A Tutorial. Adv. Methods Pr. Psychol. Sci. 2019, 2, 77-101. [CrossRef]

27. Agresti, A. The Analysis of Ordinal Categorical Data; John Wiley and Sons: New York, NY, USA, 2010.

28. O'Connell, A.A.; Liu, X. Model Diagnostics for Proportional and Partial Proportional Odds Models. J. Mod. Appl. Stat. Methods 2011, 10, 139-175. [CrossRef]

29. Agresti, A. Categorical Data Analysis; John Wiley and Sons: New York, NY, USA, 2002.

30. O'Connell, A.A. Logistic Regression Models for Ordinal Response Variables; SAGE: Thousand Oaks, CA, USA, 2006.

31. McCullagh, P.; Nelder, J.A. Generalized Linear Models; Chapman and Hall: London, UK, 1989.

32. Peterson, B.; Harrell, F.E. Partial Proportional Odds Models for Ordinal Response Variables. J. R. Stat. Soc. Ser. C (Appl. Stat.) 1990, 39, 205. [CrossRef]

33. Fu, V. Estimating generalized ordered logit models. Stata Technical Bulletin 1998, 44, 27-30. 
34. Williams, R. Generalized Ordered Logit/Partial Proportional Odds Models for Ordinal Dependent Variables. Stata Journal: Promot. Commun. Stat. Stata 2006, 6, 58-82. [CrossRef]

35. Williams, R. Understanding and interpreting generalized ordered logit models. J. Math. Sociol. 2016, 40, 7-20. [CrossRef]

36. Liu, X.; Koirala, H. Ordinal regression analysis: Using generalized ordinal logistic regression models to estimate educational data. J. Mod. Appl. Stat. Methods 2012, 11, 242-254. [CrossRef]

37. Allison, P.D. Logistic Regression Using the SAS System: Theory and Application; SAS Institute, Inc.: Cary, NC, USA, 1999.

38. Liu, X. Ordinal Regression Analysis: Fitting the Proportional Odds Model Using Stata, SAS and SPSS. J. Mod. Appl. Stat. Methods 2009, 8, 632-642. [CrossRef]

39. Long, J.S.; Freese, J. Regression Models for Categorical Dependent Variables Using Stata, 2nd ed.; Stata Press: College Station, TX, USA, 2006.

40. Santos-Reyes, J. Factors motivating Mexico City residents to earthquake mass evacuation drills. Int. J. Disaster Risk Reduct. 2020, 49, 101661. [CrossRef]

41. Bowerman, B.L.; O'Connell, R.T. Linear Statistical Models: An Applied Approach; Duxbury Press: Belmont, CA, USA, 1990.

42. Hosmer, D.W.; Lemeshow, S.; Sturdivant, R.X. Applied Logistic Regression; John Wiley \& Sons: Hoboken, NJ, USA, 2013.

43. Brant, R. Assessing Proportionality in the Proportional Odds Model for Ordinal Logistic Regression. Biometrics 1990, 46, 1171-1178. [CrossRef]

44. Becker, J.; Paton, D.; Johnston, D.; Ronan, K.; McClure, J. The role of prior experience in informing and motivating earthquake preparedness. Int. J. Disaster Risk Reduct. 2017, 22, 179-193. [CrossRef]

45. SSN. El Sismo de 1985 en Cifras. 2021. Available online: https://web.archive.org/web/20080408054816/http://www.ssn.unam. $\mathrm{mx} /$ website/jsp/Carteles/sismo85.jsp (accessed on 20 February 2021).

46. Espinosa-Aranda, J.; Cuéllar, A.; Rodríguez, F.; Frontana, B.; Ibarrola, G.; Islas, R.; García, A. The seismic alert system of Mexico (SASMEX): Progress and its current applications. Soil Dyn. Earthq. Eng. 2011, 31, 154-162. [CrossRef]

47. Cuellar, A.; Suarez, G.; Espinosa-Aranda, J.M. Performance evaluation and classification algorithm 2(ts - tp) of the seismic alert system of Mexico (SASMEX). Bull. Seismol. Soc. Am. 2017, 107, 1451-1463. [CrossRef]

48. Griffin, R.J.; Yang, Z.; ter Huurne, E.; Bouerner, F.; Ortiz, S.; Dunwoody, S. After the flood-Anger, attribution, and the seeking of information. Sci. Commun. 2008, 29, 285-315. [CrossRef]

49. Viswanath, K.; Finnegan, R. The Knowledge Gap Hypothesis: Twenty-Five Years Later. In Communication Yearbook; Burleson, B., Ed.; SAGE: Thousand Oaks, CA, USA, 1995; Volume 19, pp. 187-228.

50. Griffin, R.J. Energy in the Eighties: Education, Communication, and the Knowledge Gap. Journal. Q. 1990, 67, 554-566. [CrossRef]

51. Klima, D.A.; Seiler, S.H.; Peterson, J.B.; Christmas, A.B.; Green, J.M.; Fleming, G.; Thomason, M.H.; Sing, R.F. Full-scale regional exercises: Closing the gaps in disaster preparedness. J. Trauma Acute Care Surg. 2012, 73, 592-597. [CrossRef] [PubMed]

52. Skryabina, E.A.; Betts, N.; Reedy, G.; Riley, P.; Amlôt, R. The role of emergency preparedness exercises in the response to a mass casualty terrorist incident: A mixed methods study. Int. J. Disaster Risk Reduct. 2020, 46, 101503. [CrossRef]

53. Witte, K. Fear control and danger control: A test of the extended parallel process model (EPPM). Commun. Monogr. 1994, 61, 113-134. [CrossRef]

54. Santos-Reyes, J. Using logistic regression to identify leading factors to prepare for an earthquake emergency during day-time and nighttime: The case of mass earthquake drills. Sustainability 2020, 12, 10009. [CrossRef]

55. Proulx, G.; Richardson, J.K. The human factor: Building designers often forget how important the reactions of the human occupants are when they specify fire and life safety systems. Can Consult Eng. 2002, 43, 35-36.

56. UNISDR (United Nations International Strategy for Disaster Reduction). Sendai framework for disaster risk reduction 2015-2030. 2015. Available online: http:/ / www.wcdrr.org/preparatory/post2015 (accessed on 17 April 2021).

57. Weichselgartner, J.; Pigeon, P. The Role of Knowledge in Disaster Risk Reduction. Int. J. Disaster Risk Sci. 2015, 6, 107-116. [CrossRef]

58. UNISDR (United Nations International Strategy for Disaster Reduction). Global Survey of Early Warning Systems; UNISDR: Geneva, Switzerland, 2006.

59. Torres, I. La alerta sísmica puede y debe mejorar, dice experto de la UNAM. 2017. Available online: https: / / www.sinembargo. $\mathrm{mx} / 24--09--2017 / 3313363$ (accessed on 20 June 2021).

60. SSA (Seismological Society of America). How Did Mexico's Early Warning System Perform During Recent Earthquakes? 2018. Available online: https:/ / www.seismosoc.org/news/mexicos--early--warning--system--perform--recent--earthquakes / (accessed on 25 June 2021). 